\title{
CHM
}

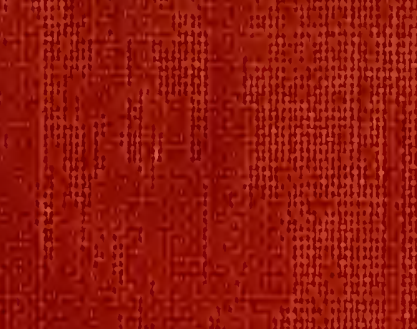

Hon? (3)

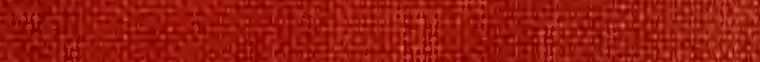
(5) to con [-10-2) Ho 19.9.

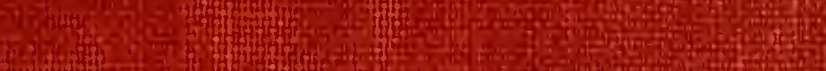
Anth

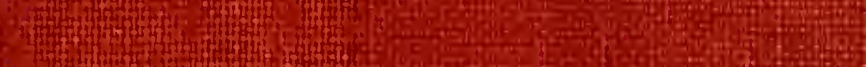
A. G5e 1.4h

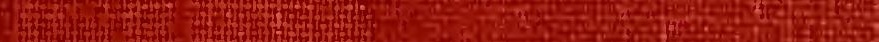
4.

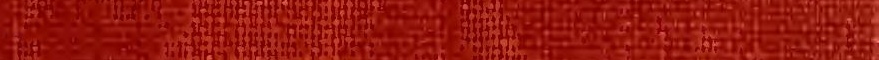
616 tof 4. (5) 4. 1. - *

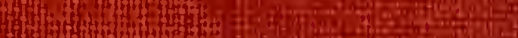

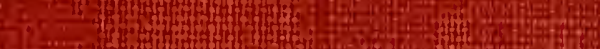

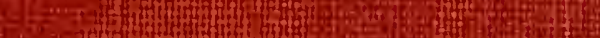
8. A 60.3 H. 3 (1) 45 50 5.

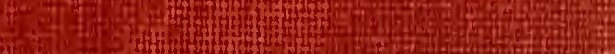





CATALOGUE

OF THE

George A. Hearn GIFT. 





\title{
CATALOGUE
}

OF

\section{ENGRAVINGS AND ETCHINGS}

PRESENTED BY

\section{GEORGE A. HEARN}

TO THE

\section{COOPER UNION MUSEUM}

FOR THE ARTS OF DECORATION

\author{
* \\ COMPILED BY \\ FITZ ROY CARRINGTON \\ $*$
}

NEW YORK 


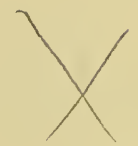

"A painfull work it is, I'll assure you, wherein what toyle hath been taken, as no man thinketh, so no man believeth, but he that hath made the triall."

Anthony ì Wood. 


\section{Index to Names of Artists, Chronologically Arranged.}

DATE PAGE

Cranach, Lucas (The Elder).............. r472-1553 7

Campagnola, Domenico.................... $\mathrm{r}_{4} 8{ }_{2}-\mathrm{r}_{5} 6_{5} 8$

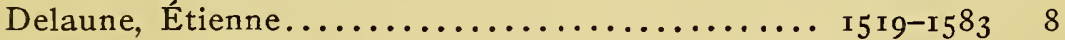

Caracci, Agostino.................... 1557-r601 9

Londerseel, Johann van.................. 1582 - 10

Ribera, Josef (Lo Spagnoletto)............... I588-16 $65^{6}$ I I

Lasne, Michel ...................... 1596-1667 I2

Van Dyck, Antoni...................... r $599-164 \mathrm{r}$ I 4

Mauperché, Henri................... r6o2-r686 r9

Cochin, Nicolas (The Elder)............... r6ı-1686 20

Cantarini, Simone (Il Pesarese).............. I6 $2-164820$

Rosa, Salvator...................... 16r5-1673 22

Castiglione, Giovanni Benedetto............ r6r6-r670 24

Poilly, François de (The Elder)............. r622-r693 25

Chasteau, Guillaume................... r6 $635-168326$

Van de Velde, Adriaan.................. r6 $635-167226$

Audran, Gérard...................... r640-r 70328

Lairesse, Gerard de................... r64I-I7II 29

Bischop, Jan de....................... I646-r686 30

Dusart, Cornelis...................... r660-1704 30

Crespi, Giuseppe Maria.................. r665-1747 $3^{1}$

Carlone, Carlo....................... 1686-r776 32

Subleyras, Pierre....................... r699-1749 33

Pazzi, Pietro Antonio.................. r706-r766 33

Chatelain, Jean Baptiste Claude........... r7ro-r77r 34

Dietrich, Christian Wilhelm Ernst.......... r712-r774 35

Tiepolo, Giovanni Domenico............... r726-r8o4 36

Cunego, Domenico................... 1727-1794 37

Morghen, Filippo.................. 1730- 38

Le Prince, Jean Baptiste............... r $733^{-178 r} 3^{8}$

Julien, Simon ........................ 1735-1800 39

Coulet, Anne Philiberte................ 1736- 39

Piroli, Tommaso.................... r $750-182440$ 
Tardieu, Pierre Alexandre ...... 1756-1844

Morghen, Raphael ..................... 176r-18 433

Laugier, Jean Nicolas................... 1785-1865 45

Leisnier, Nicolas Auguste................ 1787-1862 46

Delacroix, Eugène...................... I799-1 $863 \quad 46$

Corr, Erin......................... 1803-1 86249

Nanteuil, Célestin...................... $18 \mathrm{x}_{3}-\mathrm{x} 873 \quad 5^{\circ}$

Leroy, Alphonse............................ 5 I

Chifflart, Nicolas François............... Contemporary. 53 


\section{Index to Names of Artists, Alphabetically Arranged.}

PAGE

Audran, Gérard............................ 28

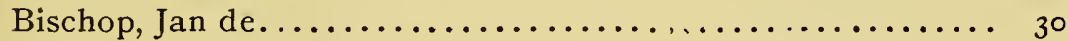

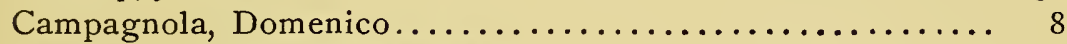

Cantarini, Simone (Il Pesarese).................... 20

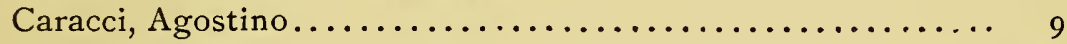

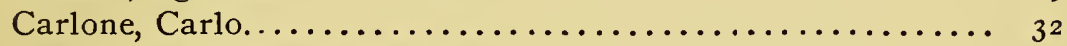

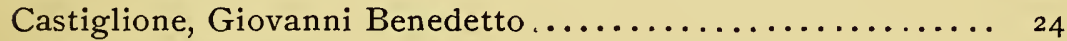

Chasteau, Guillaume........................ ${ }_{2} 6$

Chatelain, Jean Baptiste Claude ................. 34

Chifflart, Nicolas François..................... 53

Cochin, Nicolas (The Elder).................. 20

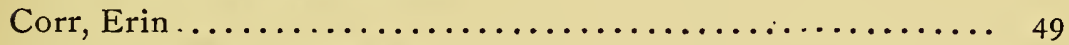

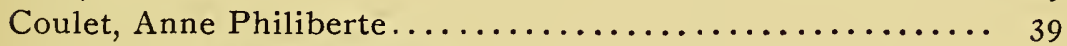

Cranach, Lucas (The Elder)................... 7

Crespi, Giuseppe Maria ....................... $3^{\text {I }}$

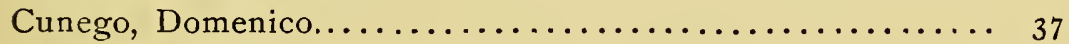

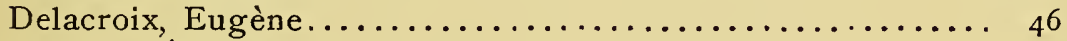

Delaune, Étienne ........................ 8

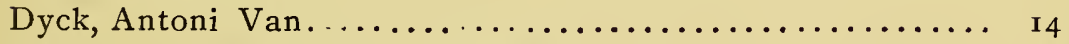

Dietrich, Christian Wilhelm Ernst............... 35

Dusart, Cornelis........................... $3^{\circ}$

Julien, Simon............................ 39

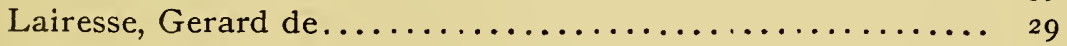

Lasne, Michel............................ I 2

Laugier, Jean Nicolas.......................... 45

Leisnier, Nicolas Auguste..................... ${ }_{46}^{6}$

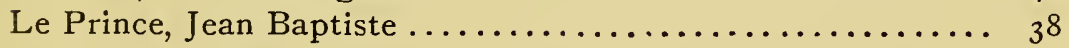

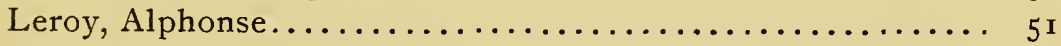

Londerseel, Johann van...................... Io

Mauperché, Henri........................ I9

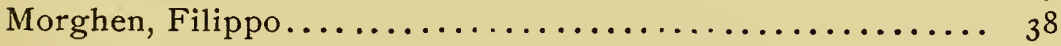

Morghen, Raphael....................... $4^{2}$

Nanteuil, Célestin........................ 50 
Pazzi, Pietro Antonio......................... 33

Pesarese, Il (Simone Cantarini).................... 20

Piroli, Tommaso........................... 40

Poilly, François de (The Elder)................... 25

Ribera, Josef (Lo Spagnoletto).................... I I

Rosa, Salvator................................

Spagnoletto, Lo (Josef Ribera).................... II

Subleyras, Pierre............................. 33

Tardieu, Pierre Alexandre....................... $4^{2}$

Tiepolo, Giovanni Domenico..................... $3^{6}$

Van de Velde, Adriaan......................... ${ }_{26} 6$

Van Dyck, Antoni............................ 4 
CRANACH, LUCAS (The Elder). [German School, I472I 553.]

Born at Kronach, in the bishopric of Bamberg, on October 4, 1472 . His real name is said to have been Sunder. A pupil of his father. In 1504 we find him established in Wittenberg as court painter to Frederick the Wise, who in 1508 bestowed on him a coatof-arms and patent of nobility. He was, evidently, a man of importance in Wittenberg, for in 1537 , and again in 1540 , he was elected Burgomaster of the town, where he carried on, besides his large art workshops, a book-printing business and an apothecary's shop. His house in Wittenberg, called the "Adler," was standing until ${ }_{1} 8 \mathrm{I}$, when it was destroyed by fire.

Cranach held the office of court painter to the House of Saxony under Frederick the Wise, his brother John, and Frederick the Magnanimous. To the last named he was so much attached, that after the battle of Mühlberg, in ${ }_{1547}$, he shared and enlivened the Elector's captivity at Augsburg, being also, it is said, instrumental in procuring his release from Charles $V$. In $155^{2}$, when the Elector was at last set free, Cranach, then a very old man, followed his lord to Weimar, where he died on October I6, 1553.

There are five engravings on copper by this master and several hundred woodcuts, for which he furnished the designs.

Bartsch describes 154 , while Heller makes mention of more than 800 .

ADAM BARTSCH, "LE PEINTRE GRAVEUR," Vol. VII., pp. 273-30I. JOSEPH HELLER, "LUCAS CRANACH'S LEBEN UND WERKE."

CHRISTIAN SCHUCHARDT, "LUCAS CRANACH DES ALTERN LEBEN UND WERKE."

\section{Christ Mocked.}

One of a series of fifteen woodcuts (Bartsch, Nos. 6-20) illustrating the Passion of Jesus Christ. 


\section{CAMPAGNOLA, DOMENICO. [ITALIAN School, I482(?)- I565. (?)]}

Born at Padua about 1482 , and worked there in the earlier half of the sixteenth century. He was at first a pupil of his relative, Giulio Campagnola, and, later, of Titian (who is said to have been jealous of his talent). In $\mathrm{r} 5 \mathrm{II}$ he was Titian's assistant at Padua and Vicenza. He probably accompanied this master to Venice, and lived there for some time. Most of his paintings, both in oil and in fresco, are in Paduan churches. His frescoes in the Scuola del Santo (Padua) almost rival those of Titian, in the same place.

Bartsch catalogues ten engravings on metal and five on wood by this artist. Passavant adds six more engravings on metal, and discusses a number of others on wood and metal. It seems to be almost certain that the wood engravings bearing his name were not actually cut on the block by Campagnola. He furnished the designs, and the cutting was done by other hands.

ADAM BARTSCH, "LE PEINTRE GRAVEUR," Vol. XIII., pp. 377-387.

J. D. PASSAVANT, “LE PEINTRE GRAVEUR," Vol. V., pp. I67-I 73 .

\section{The Massacre of the Innocents.}

St. Matthew, chap. ii., I6-18.

Bartsch, No. I.

From the collection of A. Firmin-Didot.

This print bears, in the lower margin, the monogram of Luca Antonio di Giunta, and would seem, certainly, to have been cut on the block by this engraver, after a design by Campagnola.

"The Massacre of the Innocents" was a favorite subject with the older masters, and is, in this cut, treated with great boldness and spirit.

\section{DELAUNE, ÉTIENNE. [French School, I5I9-I583.]}

Born in Paris in 1519.

He commenced his career as an engraver of medals, and is said to have been helped by Benvenuto Cellini, who was, at that time, living in Paris. He afterwards engraved many plates after Raphael and the Italian masters of Fontainebleau, and still more after the designs of his son, Jean. He was to the French School of 
Engraving what Beham, Aldegrever and Binck were to the German School, but his plates are characterized by a richer invention and a more pleasing and softer style of execution than theirs.

He died in Paris in 1583 .

His prints are usually signed with the letter S., the initial of the Latin form of his Christian name-Stephanus.

A. P. F. ROBERT-DUMESNIL, "LE PEINTRE GRAVEUR FRANÇAIS," Vol. IX., pp. I6-г 30.

\section{The Massacre of the Innocents.}

Robert-Dumesnil, No. 299.

Copy in reverse, and smaller, of Marc Antonio's engraving after a drawing by Raphael. (For Marc Antonio's plate, see the George C. Cooper Collection.)

Alexander Putting Away the Books of Homer in a Casket Taken from Darius.

Robert-Dumesnil, No. 3 о I.

Copy in reverse, and smaller, of Marc Antonio's engraving from a bas-relief.

The Martyrdom of Saint Felicitas (or Saint Cecilia).

Robert-Dumesnil, No. 306.

Copy in reverse, and smaller, of Marc Antonio's engraving after a drawing by Raphael for the fresco in the chapel of the Villa Magliana.

CARACCI, AGOSTINO. [Italian School, I557-I60I.]

Born at Bologna in 1557 . The elder brother of Annibale Caracci and cousin of Lodovico Caracci.

He was intended by his father for the profession of a goldsmith and at the age of fourteen had engraved some plates, when he was persuaded by Lodovico to study painting. He accordingly 
became a pupil of Prospero Fontana and, later, learned the art of modelling with the sculptor Minganti, and pen drawing with Bartolomeo Passerotti.

On leaving the school of Passerotti, Agostino, together with his brother Annibale, passed some time at Parma, studying the works of Correggio and Parmegiano. He afterwards went to Venice, where he had an opportunity of perfecting himself in engraving under Cornelis Cort, by whose instruction he became the greatest engraver of his time.

Agostino was celebrated not only as a painter and as an engraver, but we are told that he was equally distinguished in philosophy, mathematics, geography, astrology, history, poetry, medicine and music.

He engraved nearly three hundred plates, in which the correctness of his design is only equalled by the beauty of execution.

He died in I60I, and was buried in the cathedral at Parma.

ADAM BARTSCH, "LE PEINTRE GRAVEUR," Vol. XVIII., pp. 3 I-I 73.

\section{A Theatre Curtain.}

Bartsch, No. I 2 I.

From the artist's own design.

Second state, with the name of Filippo Suchielli.

$$
\text { Venus Accompanied by Cupids. }
$$

Bartsch, No. 129.

\section{The Three Graces.}

Bartsch, No. I $_{3}$.

LONDERSEEL, JOHANN VAN. [FLemish School, I582-(?).]

Born at Bruges in 1582 . He engraved a number of plates of landscape and other subjects after the paintings of Marten De Vos, Coninxlo, Winckenbooms, Goltzius and Hendrik Arts. His plates are executed entirely with the graver, and in spite of a somewhat formal style, some of them possess considerable merit.

CH. LE BLANC, "MANUEL DE L'AMATEUR D'ESTAMPES," Vol. II., pp. $5^{6}{ }^{-5}-56$. 
Abraham Meeting the Three Angels.

Genesis, chap. xviii., v. 2.

Engraved after the painting by Gillis de Hondecoeter.

\section{Jacob at the Well of Haran.}

Genesis, chap. xxix., vs. I-2.

Engraved after the painting by Gillis de Hondecoeter.

\section{Saul Anointed by Samuel.}

Ist Samuel, chap. x., v. I.

Engraved after the painting by David Winckenbooms.

Le Blanc, No. 4.

\section{Jesus Christ Praying in the Garden of Olives.}

Luke, chap. xxii., vs. 39-43.

Le Blanc, No. I4.

RIBERA, JOSEF, called LO SPAGNOLETTO. [SPANISH SchOоL, I588-1656.]

Born at Xativa (now San Felipe), near Valencia, on January 12, 1588. His parents intended that he should follow the profession of letters, and with this idea sent him to Valencia to acquire classical learning, but he there became acquainted with Francisco Ribalta, and devoted himself to the study of art under that master. He then went to Rome, where he endured great hardships for a time, living mainly on the charity of his comrades. A cardinal took pity on him and attached him to his household, but Ribera soon ran away, saying that he needed the spur of poverty to make him a good artist. After studying under Caravaggio, he went to Parma, where the grace of Correggio temporarily influenced him, but he soon returned to the style of Caravaggio, which he even exaggerated.

From Parma, Ribera went to Naples, and having there married the daughter of a rich picture dealer, was appointed Court Painter to the Viceroy, the Duke of Osuna. In I6 30 he became 
a member of the Academy of St. Luke, and in 1644 he received the decoration of the Order of Christ from Pope Innocent X. Notwithstanding his supreme position as a painter in Naples, he was jealous of the advancement of others, and was the leader of the infamous cabal that drove Annibale Caracci, Guido Reni, Gessi and Domenichino from the city.

Among his pupils were Salvator Rosa, Giordano and Giovanni Dô. His paintings are generally sombre or terrible, and represent flayings, scourgings and scenes of death.

Ribera died in Naples in 1656.

Bartsch catalogues eighteen etchings by this master, and ranks them among the most remarkable productions of the art. His drawing is pure and correct. He etched freely and with fine taste, and adapted his style to the various objects represented. Some of his plates are slightly retouched with the burin, but in so artistic a manner that, though the effect is strengthened, the harmony is never disturbed.

ADAM BARTSCH, “LE PEINTRE GRAVEUR," Vol. XX., pp. 77-88.

\section{Saint Jerome.}

Bartsch, No. 4 .

\section{The Martyrdom of Saint Bartholomew.}

Bartsch, No. 6.

This etching is the artist's masterpiece, and good impressions of it are very rare.

LASNE, MICHEL. [FreNCH SCHOOL, I596-I667.]

Born at Caen, in Normandy, in 1596 . Lasne was one of the first of the French engravers to distinguish himself by a free and dexterous management of the graver. He was very industrious and engraved a great number of plates, including portraits, historical and religious subjects.

He died at Paris in $\mathbf{1 6 6 7 .}$

\section{The Sermon on the Mount.}

St. Matthew v., vi., vii. 
Christ and the Centurion.

St. Matthew viii., 5-I3.

\section{The Parable of the Sower.}

St. Matthew xiii., 3-9; 18-23. St. Luke viii., 5-15.

Christ's Miracle of the Loaves and Fishes.

St. Matthew xiv., r5-21 ; xv., 32-38.

Christ Walking on the Sea.

St. Matthew xiv., 22-3r.

Christ Healing the Daughter of the Woman of Canaan.

St. Matthew xv., 2I-28.

The Entry into Jerusalem.

St. Matthew xxi., $\mathbf{I}-9$.

St. Mark xi., I-Io.

The Parable of the Talents.

St. Matthew xxv., I4-30.

Christ Meeting the Officers from the Pharisees.

St. John xviii., $1-5$.

\section{Zacchaus the Publican.}

St. Luke xix., $x-5$. 
Christ Carrying His Cross.

St. John xix., I6-I 7 .

\section{The Crucifixion.}

St. Matthew xxvii., 33-5I.

St. Mark xv., 22-38.

St. Luke xxiii., 32-49.

St. John xix., $18-24$.

\section{The Entombment of Christ.}

St. Matthew xxvii., 57-61.

St. Luke xxiii., 50-56.

St. Mark xv., 42-47.

St. John xix., $38-42$.

The Resurrection.

St. Matthew xxviii., I-8.

St. Luke xxiv., I-I 2.

St. Mark xvi., I-8.

St. John xx., I-IO.

Peter and John at the Gate of the Temple. Acts iii., I-7.

Saint Philip Baptizing the Ethiopian.

Acts viii., 8.

VAN DYCK, ANTONI. [Flemish School, I599-1641.]

Born in Antwerp, March 22, I599. At ten years of age he was apprenticed by his father, Frans Van Dyck, to Hendrik van Balen, and at sixteen entered the studio of Rubens, where, first as pupil, and, later, as assistant, he remained until i620. Rubens' affection for his talented pupil showed itself in numerous acts of kindness; as in $162 \mathrm{I}$, when he presented Van Dyck to the Countess of Arundel, through whom he obtained access to King James I., whose portrait he painted at Windsor; and in the autumn of the same year, when he sent the Chevalier Varni with him to Italy, 
and gave him a horse for the journey. Van Dyck reached Rome in February, 1623, but it was not until the following year, after he had visited Florence, Bologna, Venice and Mantua, that he took up his residence there, and made himself known by painting the admirable portrait of Cardinal Bentivoglio. The success of this portrait excited the jealousy of Van Dyck's fellow artists, who made Rome so intolerable to him that in June, 1625 , he left that city for Genoa, where he remained until the next year, when he returned to Antwerp.

After an unsuccessful visit to England, where he failed to obtain presentation at court for want of favor with the Duke of Buckingham, Van Dyck returned to Antwerp, and it was during the next three years that many of the splendid portraits which, later, were engraved for the "Iconography," were painted.

In April, r632, Van Dyck, at the request of Charles I., returned to England, and was presented, by Sir Kenelm Digby, to the King, whose portrait, as well as that of the Queen, he painted. On July $5,6_{3} 2$, he was knighted and appointed court painter, and in October, 1633 , had a pension of $£ 200$ a year assigned to him. During the next nine years he painted 19 portraits of the King and 17 of the Queen, as well as many portraits of their children, at a fixed price of $£ 50$ for half-length and $£$ roo for full-length figures.

Living in a style of splendor beyond his means, Van Dyck became more and more embarrassed as the troubles of Charles" reign thickened, until in 1638 he presented a statement of his. unpaid claims, including his pension for the past five years and payment for many portraits.

These claims were but partially satisfied in $164 \mathrm{I}$ when he went to France, hoping to obtain the commission to decorate the galleries of the Louvre, which was given to Poussin, through the influence of Cardinal Richelieu.

Disappointed, and in broken health, he returned to London, and on December 9, I64I, died at Blackfriars. He was buried in St. Paul's Cathedral.

WILLIAM HOOKHAM CARPENTER, "PICTORIAL NOTICES OF ANTHONY VAN DYCK."

WILLIS O. CHAPIN, "THE MASTERS AND MASTERPIECES OF ENGRAVING," PP. II $3-115$.

GEORGES DUPLESSIS, "THE WONDERS OF ENGRAVING," pp. I32I35.

P. G. HAMERTON, "ETCHING AND ETCHERS," pp. Io7-IO9. 
HERMANN WEBER, “CATALOGUE RAISONNÉ D’UNE COLLECTION DE PORTRAITS GRAVÉS PAR ET D'APRÈS ANTOINE VAN DYCK."

FR. WIBIRAL, “L'ICONOGRAPHIE D'ANTOINE VAN DYCK.”

"No true critic can be indifferent to Vandyke. He is one of the great princes of the art, a royal master who is to be spoken of only with the most profound respect. He had all the great qualities; he had perfect freedom and exquisite refinement; he used the needle with admirable ease and grace, and his masterly force was restrained and tempered with a cultivated severity . . . Of Vandyke himself as an etcher, little more is to be said than the few sentences already written. His aims were few, his choice of means instinctively wise and right, his command of them absolute, his success complete." (P. G. Hamerton, "Etching and Etchers," pp. 107-ro8.)

The following description (written by Mr. Atherton Curtis) of the "Iconography," and of the artists whose works appear in it, was printed as an introduction to a "Catalogue of an exhibition of the original etchings by Van Dyck, and of portraits engraved under his direction after his own paintings and drawings."

This exhibition was made at the gallery of Messrs. Frederick Keppel \& Co., New York (February 25-March I3, I897).

"During the course of his travels Van Dyck met almost all the famous men and women of his day, and of many of them he painted or drew portraits. About the year 1632 the idea occurred to him of publishing a selection of these portraits in the only form then practicable, that of engraving. He engaged the best engravers of his time, and for a number of years these men worked under his supervision, copying his portraits and following as nearly as they were able the directions of the master. The result of their joint labors was the celebrated series of portraits known as the 'Iconography of Van Dyck.' The series was first published by Van den Enden, from whom the plates passed to Gillis Hendricx, who added a number of new ones to the set, and among them some original etchings by Van Dyck himself. From Gillis Hendricx the plates passed to one publisher after another, until they finally found a resting-place in the Louvre Museum, where impressions are still printed from them, impressions, unfortunately, of no great value, mere ghosts of the once brilliant masterpieces.

We have said that in preparing the plates for publication the engravers worked under Van Dyck's direction. Thus he held himself in a way personally responsible for the results, and the finished plates may be said to be the combined work of Van Dyck 
and his engravers. Sometimes the master began by etching the plates himself in order to guide the engraver in his work, and this, no doubt, was the origin of some of his original etchings. That these, in most cases at least, were intended merely as a groundwork for the engraver, is shown by the later states of many of the plates, in which little remains of what Van Dyck himself drew upon them. For some unknown reason some of his own plates were saved from the burin of the engraver. Others, too, were spared in part, the backgrounds and draperies being worked over by other hands, while the heads were left as the master etched them. Thus we have eighteen portraits which in their early states are originals by Van Dyck himself, and in their later states are in whole or in part his work. Few as these are in number, their brilliant treatment places Van Dyck among the great masters of etching. The chief characteristics of his plates are extraordinary fidelity in giving the likeness and the character of the persons represented. In technical treatment they are thoroughly original, and are extremely simple, both in the drawing of the figures and in the handling of the draperies. Certainly the portraits of Van Dyck himself, of Snyders, of Triest, of Frans Franck, of Adam Van Noort, and of Johan de Wael, to mention but six, are works that can stand comparison with the best portraits of even Rembrandt himself, the great master of etching. Besides his eighteen portraits Van Dyck has left us the 'Erasmus' and two other etchings, one a plate after Titian, the other an original composition, 'Christ Mocked,' very grand and very striking in early impressions before the plate was retouched by other hands.

Of the engravers who were employed by Van Dyck, Peter de Jode, Paul Pontius, Lucas Vorsterman, Schelte à Bolswert, Neefs, Galle, Van Voerst, Hondius and Hollar are among the best known. The last is more celebrated for his original work than for his engravings after others, and his difficulty in lending himself to Van Dyck's style may have been the reason for the master's not employing him more frequently upon his plates. Lucas Vorsterman is the engraver who, in general, gave himself over most readily to Van Dyck's influence, and in a joint undertaking of this kind the assimilation of the director's style was necessarily important, for the nearer the engraver approached the master in his work the more faithful would be his interpretation of the original drawing or painting. Whether or not Van Dyck worked upon any of the plates after they had been given to the engraver is a question that cannot be decided; but be this as it may, one thing is certain, that under his supervision a series of engraved portraits was pro- 
duced which, making all due allowance for occasional inequalities, is one of the most valuable of our sources of information upon the people of the seventeenth century."

\section{Portrait of Jan Breughel.}

Wibiral, No. I. Carpenter, p. 85. Weber, p. 2 I.

Sixth state, with the letters "G. H." erased.

Jan Breughel, called "Velvet Breughel," was born in Brussels in ${ }_{5}$ 68. He was the son of Pieter Breughel, the elder, and a pupil of Pieter Goetkint at Antwerp. His works were greatly esteemed by his contemporaries, and he often worked in conjunction with Van Balen, Rottenhammer and Rubens, with whom he was allied in close friendship. He painted landscapes, animals and still life, also genre and mythological subjects.

He died in Antwerp, January I3, 1625.

\section{Portrait of Jan Snellinx.}

Wibiral, No. 37. Carpenter, p. 106. Weber, p. 3 .

Fifth state, with the letters "G. H." erased.

Dr. Louis Thies states that Van Dyck painted and etched this portrait twice. This is the finished plate of the second etching, finished with the burin, by Pieter de Jode, the younger.

Wibiral is of the opinion that Van Dyck etched one plate only of Jan Snellinx. (Wibiral, No. Iо.)

Jan Snellinx was born at Mechlin in I544. His best works are his paintings of skirmishes and cavalry. He lived at Antwerp, where he was much employed, and was appointed court painter to Albert and Isabella, the governors of the Netherlands. He was twice married, and no fewer than five of his sons were painters.

He died at Antwerp in $16{ }_{3} 8$.

Pieter de Jode, the younger, was born in Antwerp in 1606 . He was a pupil of his father, Pieter de Jode, the elder, whom he surpassed in the taste and facility with which he handled the graver. He engraved over three hundred plates, but they are very unequal in merit. His best works are his portraits, a number of which he engraved after the paintings of Van Dyck.

He died in Brussels in 1667. 


\section{Portrait of Franz Snyders.}

Wibiral, No. זr. Carpenter, p. ro7. Weber, p. 3 I.

Fourth state, with the letters "G. H." erased.

Van Dyck etched the head and collar only. Jacob Neeffs finished the plate with the burin, but he left the head exactly as etched by Van Dyck.

Engraved after the picture in the collection of the Earl of Carlisle, at Castle Howard, "one of the finest of the master-and of all portraits," with a change in the position of the hands.

A similar picture is in the Munich Gallery.

Franz Snyders was born at Antwerp in r 579. He was a pupil of Hendrik Van Balen and Pieter Breughel. His first pictures were of still life, but he afterwards devoted himself to painting animals and hunting scenes. Rubens frequently employed him to paint the animals, fruit, etc., in his pictures. He was invited to Brussels by the Archduke Albert, and for him Snyders painted some of his finest works, particularly a stag hunt, which was sent by the Archduke to Philip III. of Spain, who commissioned Snyders to paint several large pictures of combats of wild beasts, and hunting scenes, which are still in the old palace of Buen-Retiro.

He died at Antwerp in 1657 .

Jacob Neeffs was born in Antwerp about r630. He distinguished himself by the plates he engraved after the paintings of Van Dyck, Rubens and other celebrated painters of the Flemish School. His works are mainly executed with the burin.

\section{MAUPERCHÉ, HENRI. [FRENCH SCHOOL, 1602-1686.]}

Born at Paris in 1602 . During the reigns of Louis XIII. and Louis XIV. he enjoyed a certain amount of celebrity, and the fourteen landscapes in fresco which he painted in the large room at Fontainebleau show that his reputation was well deserved. $\mathrm{He}$ was one of the original members of the Academy, was elected Professor in 1655 , and died in Paris in 1686.

There are fifty-one etchings by him. They are etched in a light and spirited manner, and good impressions are, on this account, very rare, as the plates soon wore out.

A. P. F. ROBERT-DUMESNIL, "LE PEINTRE GRAVEUR FRANÇAIS," Vol. I., pp. 39-73. 
John the Baptist Preaching in the Desert.

Robert-Dumesnil, No. 24.

\section{The Punishment of Marsyas.}

Robert-Dumesnil, No. 27.

\section{The Bridge Under the Highroad.}

Robert-Dumesnil, No. 46.

COCHIN, NICOLAS (The Elder). [FRENCH School, I6ro-I686.]

Born at Troyes in 16 ro. The son of the painter, Noel Cochin. About 1635 he went to Paris, where he died in 1686 . He engraved several hundred plates, the most important being those which he executed for the "Glorieuses Conquêtes de Louis le Grand," published between the years 1676 and 1694 .

Nicolas Cochin is the best engraver Troyes has produced. His drawing is firm, and his engraving fine and delicate.

CORRARD DE BREBAN, "GRAVEURS TROYENS."

Franche-Comte Conquered for the Second Time, 1674 .

Engraved after the painting, by Charles Le Brun, on the ceiling of the "Gallerie des Glaces," Versailles. One of a gigantic series of Allegories commemorating the achievements of Louis XIV.

CANTARINI, SIMONE, called IL PESARESE or SIMONE DA PESARO. [Italian School, 16I2-I648.]

Born at Oropezza, near Pesaro, in 1612. He was instructed in design by Giovanni Giacomo Pandolfi, and afterwards studied under Claudio Ridolfi. Although he had, by this time, gained no 
little celebrity by his painting, the works of Guido Reni were so much the object of admiration that he resolved to become a student in the school of that master, in Bologna, where he remained until his insolence and malevolence, not only to his instructor, but to Domenichino and Albani, obliged him to leave Bologna and seek shelter in Rome, where he employed some time in studying the works of Raphael. On his return to Bologna, not finding residence there agreeable to him, he went to Mantua, where he was taken into the service of the Duke, and employed to paint his portrait. But whether he had not been accustomed to that branch of art, or from some other cause, he was entirely unsuccessful. This disappointment, preying on a disposition naturally morose and irritable, is supposed to have occasioned his death, though it is attributed by some writers to the effects of poison. He died October 15,1648 .

As a painter Cantarini is acknowledged to have more nearly approached to Guido Reni than any of the other imitators of that master. Many of his best works possess great beauty, but he is indebted to his master for the qualities that render them beautiful.

In etching, the grace of his figures and the purity and correctness of his drawing (above all in the extremities) is admirable.

He was less skilful in rendering the flow of drapery, and in this respect is far inferior to Guido Reni.

He etched thirty-seven plates in a manner very similar to that of Guido Reni, several of them being of a quality equal to the work of that master.

ADAM BARTSCH, "LE PEINTRE GRAVEUR," Vol. XIX., pp. I 20-I46.

Adam and Eve.

Bartsch, No. I.

\section{Christ Bearing His Cross.}

Bartsch, No. 20.

\section{Christ Bearing His Cross.}

Copy of Guido's etching, Bartsch, No. 20.

The very deceiving copy described by Bartsch. It is detected by the variation in the horizontal lines between the clouds, just above the head of Christ. 


\section{Saint Sebastian.}

Bartsch, No. 24.

\section{Saint Sebastian.}

Copy in reverse of Guido's etching, not described by Bartsch.

Jupiter, Neptune and Pluto Honoring the Arms of Cardinal Borghese.

Bartsch, No. 29.

Third state, with the arms erased. Pluto, standing on a chariot drawn by two horses, is seen advancing from the left of the print. He extends his crown toward the shield, which, in the first and second states of the plate, bears the arms of Cardinal Borghese.

\section{Mercury and Argus.}

Bartsch, No. 3 I.

This print is considered one of the artist's finest works. Argus is reclining on the ground, and is listening with attention to Mercury, who, in the disguise of a shepherd, is playing the flute.

\section{Mars, Venus and Cupid.}

Bartsch, No. $3^{2}$.

Etched after a painting by Paul Veronese.

This impression is, seemingly, later than the state described by Bartsch, for it bears in its lower margin "P. Veronensis. in," not mentioned in his description, as well as the "P. C. I." (Paulus Caliari invenit) of which Bartsch speaks.

ROSA, SALVATOR. [ITAlian School, I6I5-I673.]

Born at Renella, near Naples, on June 20, I6I5. His parents intended him for the Church, and with this view sent him to the College of the Congregazione Somasca, at Naples. His impetuous 
character and temperament seem to have brought him into trouble, and he left the college before his education was completed. $\mathrm{He}$ returned home and commenced the study of art with his brotherin-law, Francesco Fracanzano. When about eighteen years of age, becoming impatient of control, he left Naples and made a sketching tour through the Abruzzi, and there joined a party of bandits. To this sojourn may be traced many of those robber pictures which so specially distinguish him.

On his return home he was obliged, by the death of his father, to provide for the needs of the poverty-stricken family. Oppressed by want and privation he used to expose his pictures for sale on the street, until one day he was fortunate enough to attract the attention of Lanfranco, who befriended him, and also gained for him the friendship of Aniello Falcone. He seems, however, to have been still very poor, and in 1634 left Naples for Rome. Here he supported himself by his sketches until ill health compelled him to return to Naples.

Soon after his return, however, he was persuaded to accompany his fellow-student, Girolamo Mercuri, who had been appointed Chamberlain to Cardinal Brancaccia, back to Rome. This led to his being commissioned to paint the portico and loggia of the Cardinal's palace at Viterbo, and to other works. After a visit to Naples he again went to Rome in I6 39 , and soon became famous as a painter, a musician and a satirical poet. In I647, hearing of the insurrection of Masaniello, he hastened to Naples and joined the Compagnia della Morte, led by Falcone. On the downfall of Masaniello he returned to Rome, where he got into trouble by a satirical picture, and therefore accepted the invitation of the Grand Duke to visit Florence. In $165^{2}$ he returned to Rome, in which city he died on March 15,1673 .

As an etcher, Salvator Rosa is chiefly distinguished for the variety, life and movement of his figures, although they are often incorrect in drawing. He etched eighty-six plates. They include religious, historical and mythological subjects, also a number of studies of soldiers, mostly single figures.

ADAM BARTSCH, "LE PEINTRE GRAVEUR," Vol. XX., pp. 266-292.

\section{Diogenes and Alexander.}

Bartsch, No. 6. 
The Philosopher Democritus Contemplating the End of All Things.

Bartsch, No. 7 .

\section{Edipus Exposed on Mount Citharon.}

Bartsch, No. 8.

\section{CASTIGLIONE, GIOVANNI BENEDETTO. [ITALIAN Sсноог, I6I6-I670.]}

Born at Genoa in r6r6. He studied first under Giovanni Battista Paggi, and then entered the school of Giovanni Andrea de' Ferrari. He is also said to have had lessons from Van Dyck, but as Castiglione was only nine years old at the time of Van Dyck's departure from Genoa, it is probable that he merely studied Van Dyck's works.

Castiglione painted in Florence, Rome, Venice, Naples, Bologna and Mantua, in which city he entered, about 1654 , the service of Duke Charles I. He soon won a great reputation, and received orders from France, England and Germany. He is best known by his landscape and pastoral pictures, although he painted also historical and religious subjects.

He died at Mantua in 1670 .

As an etcher Castiglione is deserving of special study. $\mathrm{He}$ executed sixty-seven plates with the same taste and spirit which is displayed in his paintings. The arrangement of light and shade is very fine, and recalls the work of Rembrandt.

ADAM BARTSCH, "LE PEINTRE GRAVEUR," Vol. XXI., pp. 9-42.

\section{The Finding of the Bodies of Saint Peter and Saint Paul.}

Bartsch, No. I4.

St. Peter and St. Paul are, in sacred art, frequently associated. Both suffered martyrdom in Rome. St. Peter was crucified with his head downward, while St. Paul was beheaded.

Their bodies were, in the reign of Heliogabalus, removed to 
the Catacombs and placed in the same tomb. Two hundred years later the Roman Christians removed them to the Church of the Vatican and placed them together in a magnificent silver shrine.

\section{The Festival of Pan.}

Bartsch, No. I6.

Third state, with the words Alla Pace after the date.

$$
\text { Pan Sitting Opposite a Vase. }
$$

Bartsch, No. 18.

Portrait of a Man, Turned to the Left, with a Fur Cap.

Bartsch, No. 49.

Portrait of a Man, Tumed to the Left, with a Turban and a Chain.

Bartsch, No. 5 I.

POILLY, FRANÇOIS DE (The Elder). [French School, I622-1693.]

Born at Abbeville in 1622. A pupil of his father, a goldsmith and engraver. Later he went to Paris and studied for three years under Pierre Daret, afterwards visiting Rome, where he took Cornelis Bloemaert as his model. He remained in Rome seven years and in 1656 returned to Paris, where he became one of the most celebrated engravers of his time and country. In 1664 he was appointed Engraver to the King, and died in 1693.

His plates are executed entirely with the burin, which he handled with uncommon firmness and dexterity.

\section{Mater Dolorosa.}

Engraved after the painting by Guido Reni. 
CHASTEAU, GUILLAUME. [French School, I635-1683.]

Born at Orleans, April 18, I635. He was first instructed by Greuter, but afterwards studied under Cornelis Bloemaert, and went for further improvement to Italy. After passing several years at Rome he returned to Paris, where he was employed by Jean Baptiste Colbert (successor to Cardinal Mazarin as Minister of Finance), whose portrait he engraved. Among his first works are a series of the portraits of the Popes. He afterwards engraved, besides some portraits, a number of plates after the paintings of Nicolas Poussin, also some after the works of the Italian painters-Annibale Caracci, Raphael, Pietro da Cortona, Correggio and Albani.

Some of his plates are executed entirely with the graver, in the style of Poilly and Bloemaert, whilst others are etched. Some authorities prefer his etched to his engraved work, the former being free and spirited.

He was made a member of the Academy in $166_{3}$, and died in Paris the ${ }_{5} 5^{\text {th }}$ of September, 1683 .

\section{The Martyrdom of Saint Stephen.}

After the painting by Annibale Caracci. This engraving is of the same size as the original picture.

\section{VAN DE VELDE, ADRIAAN. [Dutch School, I635 оR $\left.16{ }_{3} 6-167^{2}.\right]$}

Born in Amsterdam in 1635 or 1636 .

A pupil of his father, Willem Van de Velde, the elder, a marine painter. At a very early age Adriaan showed a remarkable talent for painting, but his bent was rather toward landscape and cattle, sheep and goats, than marine subjects. He entered the school of J. Wynants, at Haarlem, and afterwards studied the figure with Philip Wouwerman. He was much employed by contemporary artists to insert figures in their compositions, and among those whom he thus assisted were Hobbema, Van der Heyden, Wynants and the Ruisdaels.

He left numerous works, considering the shortness of his life. He died January 21,1672 .

The exact number of his etchings is not known. Bartsch de- 
scribes twenty-one. To these Immerzeel adds three landscapes with figures, and one plate of a cow lying in a field. Bartsch's statement that five of Van de Velde's plates were etched at the age of fourteen is repeated in "Bryan's Dictionary of Painters and Engravers," though here the date of his birth is given as 1635 or $163^{6}$, and the date on the etchings is $16_{53} !$ Bartsch makes him die, aged 33 , in 1672 . He would seem to have been $3^{6}$ or 37 years old, at the time of his death, according to the latest authorities, and 17 or 18 years old when his first plates were etched.

ADAM BARTSCH, “LE PEINTRE GRAVEUR," Vol. I., pp. 209-228.

LAURENCE BINYON, "DUTCH ETCHERS OF THE SEVENTEENTH CENTURY," pp. 77-78.

"Van de Velde's etchings are nearly all of cattle, and here he sometimes comes near Potter in drawing, while in the management of the acid he is decidedly Potter's superior. His earliest dated etching of ${ }^{6} 6_{53}$ is a large plate, which, though not powerful, has a real beauty. . . . The original design for this plate is in the British Museum. In the same collection is also the design for The Cow Lying Down (B. 2). On the same sheet of paper is a study of part of the cow in a slightly altered position, and this has been adopted in the etching. Except for this insignificant change, the two etchings are copied from the pencil studies with entire fidelity. And, probably, this was always Van de Velde's practice, as it was with Potter and Du Jardin. It is, therefore, strictly speaking, incorrect to describe the drawings as being made for the etchings. The studies were etched simply that they might be multiplied." (Laurence Binyon, "Dutch Etchers of the Seventeenth Century," p. 77.)

\section{A Cow and Two Sheep at the Foot of a Tree.}

Bartsch, No. II.

"This etching, one of the most important works of Van de Velde, is a veritable masterpiece. The truth of character, beauty of form, correctness of drawing, movement of the muscles, the tasteful way in which it is etched, the light and shade, all are of an inimitable perfection." (Bartsch.)

\section{An $O x$ and Three Sheep.}

Bartsch, No. I 2.

"This piece is of equal beauty to the preceding." (Bartsch.) "None of the studies of cattle, etched by the Dutch masters, 
surpasses Van de Velde's set of three, numbered II, I 2 and 13 in Bartsch. Potter never produced an effect so delicate and so rich in color as Van de Velde in these three etchings. At the same time there is no ostentation of skill; rather there seems a kind of modesty in the workmanship that is quite winning." (Laurence Binyon, "Dutch Etchers of the Seventeenth Century.")

\section{The Ewe.}

Bartsch, No. I4.

"This piece is etched in the same year $(1670)$ as the three preceding pieces (Bartsch, Nos. I I, I2, I3), but it even surpasses them in delicacy." (Bartsch.)

\section{The Two Sheep.}

Bartsch, No. I5.

\section{A Goat.}

Bartsch, No. I6.

"These five plates, together with 'Two Cows at the Foot of a Tree' (Bartsch, No. I3), form a set. They are very rare, especially this last one, which is exceedingly rare." (Bartsch.)

\section{AUDRAN, GÉRARD. [French School, 1640-1703.]}

Born at Lyons on August 2, 1640.

After learning the principles of design and engraving from his father, Claude Audran, the elder, and from his uncle, Charles Audran, he went to Paris to receive instruction from Le Brun, and afterwards to Rome, where he is said to have studied under Carlo Maratti. During a residence there of three years he engraved some plates which gained him so great a reputation that Louis XIV. was induced to invite him to return to Paris, and soon after his arrival appointed him Engraver to the King, with a considerable pension and apartments in the Gobelins.

Audran now applied himself, with great assiduity, to engraving "The Battles of Alexander" after the paintings of Charles Le Brun. 
These are some of his finest plates and will ever remain a lasting monument to the engraver.

In 1675 he apparently paid a second visit to Rome, but, later, returned to Paris, where he died on July $26,1703$.

A. P. F. ROBERT-DUMESNIL, "LE PEINTRE GRAVEUR FRANÇAIS," Vol. IX., pp. $237-322$.

WILLIS O. CHAPIN, "THE MASTERS AND MASTERPIECES OF ENGRAVING."

GEORGES DUPLESSIS, "LES MERVEILLES DE LA GRAVURE."

"Gérard Audran was one of the most skilful draughtsmen of the French School, and his works are characterized by good taste, truth, sentiment and originality, as well as by great technical skill and remarkable effects of chiaroscuro. He combined with the greatest success the work of the burin and needle in a broad, original style especially suited to his subjects. In his battle-pieces he improved upon his originals in many respects, and in his own time acquired a reputation greater than that of either Nanteuil or Edelinck." (Willis O. Chapin, "The Masters and Masterpieces of Engraving," p. I54.)

\section{The Martyrdom of Saint Andrew.}

Engraved after the painting by Charles Le Brun.

\section{LAIRESSE, GERARD DE. [Dutch Schoоl, I64I-I7Ir.]}

Born at Liége in $\mathbf{r} 64 \mathrm{I}$. He was instructed by his father, Renier de Lairesse (an artist of some celebrity), in belles-lettres, music and the principles of design. He afterwards studied under Bertholet Flemalle, and at the age of sixteen had made himself known as a portrait painter. Not finding sufficient employment in his native city he moved to Utrecht, and soon afterwards to Amsterdam, where he was regarded as the greatest historical painter of his time. In 1690 he lost his sight, but he continued, until his death, to communicate his ideas on the theory and practice of art, in a series of discourses, which were collected and published after his death.

He died at Amsterdam in I 7 II.

As an etcher Gerard de Lairesse claims particular notice. He 
etched a number of plates from his own designs, executed with great freedom and spirit. The lights are broad and powerful, and the eye is carried at once to the principal figures of the composition.

$$
\text { Spring. }
$$

Summer.

Autumn.

\section{Winter.}

These four plates, of the Four Seasons, are etched from his own designs for ceilings.

BISCHOP, JAN DE. [Dutch School, I646-I686.]

Born at the Hague in 1646 . He engraved over a hundred plates, some being after the works of the Italian masters.

He died at Amsterdam in 1686.

He signed his name in its Latin form-"Episcopius," and his monogram is, therefore, composed of the letters J. and E.

CH. LE BLANC, "MANUEL DE L'AMATEUR D'ESTAMPES," Vol. I., p. 348 .

ANDREAS ANDRESEN, " HANDBUCH FÜR KUPFERSTICHSAMMLER," Vol. I., p. 127.

\section{The Laocoön.}

The original marble group is now in the Vatican.

DUSART, CORNELIS. [DUTCH School, I660-I704.]

Born at Haarlem, April 24, 1660 . He was a pupil of Adriaan van Ostade, whose style he imitated with considerable success. In I679 he entered the guild of painters, at Haarlem, and died in that city on October 4,1704 .

He etched sixteen plates, and also engraved a number of 
plates (Bartsch catalogues 34 as genuine) in mezzotint, from his own designs.

"Some of Dusart's etchings have a pleasing effect, with wellmanaged light and shade; but they cannot be compared with the similar pieces by Ostade, whose method is here carried on, but in an inferior manner. Yet he has a vein of his own, a gross, riotous, extravagant vein, with a great fondness for violent action." (Laurence Binyon, "Dutch Etchers of the Seventeenth Century," p. 34.)

ADAM BARTSCH, "LE PEINTRE GRAVEUR," Vol. V., pp. 465-490.

LAURENCE BINYON, "DUTCH ETCHERS OF THE SEVENTEENTH CENTURY," p. 34.

\section{The Violinist Seated.}

Bartsch, No. 15.

In shading this plate Dusart has made use of the "rocker" (a tool used in engraving mezzotint plates). This added work is especially noticeable in the light space in front of the violinist.

"In the plate called by Bartsch Le Violon Assis (B. I5) his specific qualities appear to great advantage. One seems to hear an hilarious din merely from looking at it. The fiddler plays with a wild fantastic energy ; one peasant accompanies him with crashing tankard and roaring chorus; another sits bent and sullen with his head on his hands. The landlord, with huge frame and round paunch, looks on with twinkling eyes. A woman by the great chimney, on which hangs the notice of a sale of tulips and hyacinths, 'Tulpan en Hyacinthen,' calls a child to her. The roomy background, with its beams and rafters, is drawn and lighted with extraordinary skill. As a page of daily life, fresh and vivid, this etching deserves the fullest praise." (Laurence Binyon, "Dutch Etchers of the Seventeenth Century," p. 34.)

CRESPI, GIUSEPPE MARIA. [Italian School, I665-I747.]

Born at Bologna in 1665 . He was called by his fellow-students "Lo Spagnuola" on account of the finery of his dress. $\mathrm{He}$ studied first under A. M. Toni and Domenico Canuti, then with Carlo Cignani, and finally with Antonio Burrini. He visited Venice, Parma and Modena, and painted after the style of Baroccio, 
Guercino and Pietro da Cortona. For some time he was in the employment of the Grand Duke Ferdinand, for whom he executed several works in the Pitti Palace. He died, blind, at Bologna, in I 747 .

He etched over forty plates. They are not signed with his name, but with that of Lodovico Mattioli as etcher. Mattioli was poor, and an intimate friend of Crespi's, and the latter aided him in this way. Mattioli's etchings are neither so free nor so picturesque as those of Crespi.

ADAM BARTSCH, “LE PEINTRE GRAVEUR," Vol. XIX., pp. 395-4II.

CH. LE BLANC, "MANUEL DE L'AMATEUR D'ESTAMPES," Vol. I., pp. $67-68$.

\section{The Adoration of the Kings.}

Bartsch, No. 5 .

Le Blanc, No. 4 .

After the painting by Lodovico Caracci.

\section{The Circumcision.}

Bartsch, No. 6.

Le Blanc, No. 5 .

After the painting by Lodovico Caracci.

CARLONE, CARLO. [ITALIAN School, I686-I776.]

Born at Scaria, near Como, in $\mathbf{6} 686$. His father was a sculptor and destined him for the same pursuit, but he preferred painting, and was, accordingly, placed under the care of Giulio Quaglio. $\mathrm{He}$ afterwards studied at Venice and at Rome until he was twentythree years of age, when he visited Germany, where he has left works in oil and fresco at Passau, Breslau and other cities, also at Prague and Vienna.

He died at Como in 1776 .

There are about a dozen plates by him, mostly from his own compositions.

CH. LE BLANC, “MANUEL DE L'AMATEUR D'ESTAMPES," Vol. I., p. 592 . 
Saint Carlo Borromeo Administering the Communion to the Plague Stricken.

Le Blanc, No. 4.

Etched from his own design.

SUBLEYRAS, PIERRE. [FRENCH SCHOOL, I699-I749.]

Born at Uzés, Languedoc, in 1699. A pupil of his father, Mathieu Subleyras. When he was fifteen years of age he was placed under Antoine Rivalz, of Toulouse, and in I 724, upon leaving that master, went to Paris, where, in 1727 , he obtained the first prize at the Academy for his painting of "Raising the Brazen Serpent." He then went to Rome, and met with so much success that he remained there until his death, which occurred May 28, I 749 .

Subleyras etched four plates. Three are after his own paintings, the remaining one is designed direct upon the copper.

A. P. F. ROBERT-DUMESNIL, "LE PEINTRE GRAVEUR FRANÇAIS," Vol. II., pp. $255^{-259}$.

\section{Mary Magdalen Washing the Feet of Christ.}

Robert-Dumesnil, No. 3 .

The artist's finest etching.

The original picture was painted for the Canons of San Giovanni in Laterano, and is now in the Louvre.

PAZZI, PIETRO ANTONIO. [Italian School, i706-i766.]

Born at Florence in 1706 . He was a pupil of G. Piamontini and C. Mogalli, and engraved a series of portraits of artists for the "Museo Fiorentino," Gori's "Museo Etrusco," and the "Museo Capitolino." $\mathrm{He}$ also engraved a number of plates after pictures in the Florentine galleries.

He died at Florence in 1770.

ANDREAS ANDRESEN, "HANDBUCH FÜR KUPFERSTICHSAMMLER,"

Vol. II., p. 269. 


\section{Portrait of Johann Anton Leismann.}

Johann Anton Leismann (called also Eismann and Luismon) was a German painter of landscape, battle and seaport pictures. He was born at Salzburg in 1634 , and went to Venice, where most of his works were executed, and where he died in 1698 .

\section{Portrait of Gerard Dow.}

Gerard Dow was born at Leyden, April $7,16 \mathbf{1}_{3}$, and died there February 9, I675. In 1628 he entered Rembrandt's studio, where he remained for three years. To Rembrandt he owed his harmonious treatment of the chiaroscuro and depth of color, but his careful and delicate touch precluded the free and energetic treatment of his master. His pictures generally represent the family life of the middle classes of his time.

\section{Portrait of Marcantonio Franceschini.}

Marcantonio Franceschini was born at Bologna in 1648 , and died there in I729. He was the favorite pupil of Cignani, and, later, his assistant. He was the head of a school in Northern Italy similar to that of Pietro da Cortona in Lower Italy.

\section{CHATELAIN, JEAN BAPTISTE CLAUDE. [FRENCH SchоOL, I7IO-I77.]}

Born at Paris in I710. It is said that his real name was Philippe. He served as a French officer in the campaign in Flanders, but afterwards devoted himself to the pursuit of art. His ability was extraordinary, and had his application been equal to his talent, he might have left many fine works. Unfortunately, his life was an idle and dissolute one, and he seldom worked until compelled by necessity to do so.

He was much employed by Boydell, especially in engraving, with Vivarès, the series of landscapes after Claude, Rembrandt and others. Vivarès, being more appreciated by the public, his name was often placed on plates engraved by Chatelain alone, as in the case of the fine plate named "The Storm." He engraved, also for Boydell, eleven views in London and in Italy.

He died in London in $177 \mathrm{I}$. 


\section{The Italian Yarn-Winder.}

\section{The Italian Cook.}

Engraved from the paintings by Hubert Robert.

\section{DIETRICH, CHRISTIAN WILHELM ERNST. [GERMAN ScHOOL, I 7 I 2-I 774 .]}

Born at Weimar, October $30, \mathbf{I} 7 \mathbf{I} 2$. He was a pupil of his father, Johann Georg Dietrich, who was court painter at Weimar, and later of Alex. Thiele, the landscape painter, in Dresden. Here his talents won him the patronage of Count Brihl, and attracted the attention of Augustus the Strong, Elector of Saxony, who, in 1729, appointed him court painter. In I 734 he went to Weimar, and did not return to Dresden until I 742 . In 1743 the Elector sent him to Italy, where, in Venice and in Rome, he studied the Dutch and Flemish masters, above all, Rembrandt, Ostade and Poelenburg. He is chiefly noted for his talent in reproducing the individual style of other masters. In 745 he was made keeper of the Dresden Gallery. He was also Professor in the Academy of Arts in Dresden, and Director of the painting school at the Meissen Porcelain Factory.

He died in Dresden, April 24, 1774.

"Dietrich was exceedingly clever, manually, and very various in manner, but he was remarkable only as an unusually apt imitator of other men's work. His talent, in this respect, was nearly equal to the wonderful gift of our contemporary, Flameng, and would have been better employed in copying rare plates of the great masters than in attempting subjects of his own choosing. $\mathrm{He}$ is mentioned here because, if the reader listens much to the prevalent ideas about etchers, he may be led to waste time in studying him, and embarrass himself with speculations as to which, of all the various manners in which Dietrich worked, was the manner of Dietrich. I doubt whether he had any manner." (P. G. Hamerton, "Etching and Etchers," pp. I I 2-I I3.)

CH. LE BLANC, "MANUEL DE L'AMATEUR D'EsTAMPES," Vol. II., pp. I 27-I3I.

P. G. HAMERTON, “ETCHING AND ETCHERS," pp. II2-II3. 
Christ Healing the Sick.

Le Blanc, No. 14.

Fifth state.

Etched in the manner of Rembrandt.

Saint Philip Baptizing the Ethiopian.

Le Blanc, No. 2 r.

Etched in the manner of Rembrandt.

\section{The Satyr in the Peasant's House.}

Le Blanc, No. 25.

Etched in 739 after a painting by Jordaens.

"A satyr, having paid a friendly visit to a peasant, accepts his hospitality, and attempts to eat hot soup with a spoon, but not being accustomed to utensils of that kind, declines, with much energy of gesture, to repeat the experiment. There is plenty of vivacity in the action, and the group is engraved with considerable skill. I use the word engraved purposely, because this is rather engraving with the needle than free etching." (P. G. Hamerton, "Etching and Etchers," p. Ir6.)

The Bathers.

Le Blanc, No. 62.

A Landscape, with a Shepherd and a Shepherdess Conversing.

Le Blanc, No. $9^{2}$.

TIEPOLO, GIOVANNI DOMENICO. [Italian School, I $726-1804$.

Born at Venice in 1726 . The son and pupil of Giovanni Battista Tiepolo, who has been called "the last of the great decorative painters of the Italian School."

Domenico painted some historical subjects in the churches at 
Brescia, and then accompanied his father to Spain, where he assisted him in painting the frescoes in the palace at Madrid.

He died in Spain in 1804.

Domenico Tiepolo, as an etcher, worked in the style of Benedetto Castiglione. There are over seventy-five plates by him, executed with taste and spirit.

An Old Man Holding a Pitcher in His Left
Hand.

An Old Man with His Face Almost Hidden in His Hood.

A Man, Seen in Profile, with His Cap Turned Up in Front.

A Man, Seen Full Face, with a Square Beard and a Girdle.

CUNEGO, DOMENICO. [ITAlian School, i 727-I 794.]

Born at Verona in 1727 . He was instructed in the art of painting by Ferrari, but devoted himself afterwards entirely to engraving. His copies from the works of the Italian masters gained him a great reputation, and his plates are distinguished for their deep appreciation of the originals, excellence of design and beauty of execution.

Cunego engraved a number of plates for Hamilton's "Schola Italica," also some portraits. He afterwards went to London and engraved some plates for Boydell's collection, when he returned to Italy, and died at Rome in 1794.

Brutus Vowing Vengeance Against the House of Tarquin.

Engraved in 1768 from the painting by Gavin Hamilton. 
MORGHEN, FILIPPO. [ITALIAN School, i 730-(?).]

Born in $173^{\circ}$. After having studied for seven years at Rome, he was employed at Naples, where he carried on a trade as a printseller, and received the title of Engraver to the King of the Two Sicilies.

He was the brother of Giovanni Elia Morghen, and father of the celebrated Raphael Morghen. He executed a number of plates for the "Antiquities of Herculaneum," and a series of thirty-one plates of landscapes and views of ruins in the environs of Naples.

\section{A Bacchante.}

From a fresco at Herculaneum.

LE PRINCE, JEAN BAPTISTE. [French School, I733I781.]

Born in 1733 at Metz, where he learned the rudiments of art. He then went to Paris and studied painting under Joseph Marie Vien and François Boucher. In 1760 he went to Russia, where he remained for five years, visiting various parts of the empire and sketching the different costumes and the most remarkable views in the provinces through which he passed.

He returned to Paris with an extensive collection of drawings, from which he painted pictures, and executed plates in etching and aquatint, which were much admired. He also engraved several fancy subjects and domestic scenes from his own designs. In 1765 he became a member of the Academy, and on September $3 \circ$, I $78 \mathbf{I}$, he died at St. Denis-du-Port, near Lagny-surMarne.

The number of his plates exceeds 160 . A volume containing his work in etching and aquatint was published in 1782 under the title of " Euvres de Jean-Baptiste Le Prince. . . . contenant plus de cent soixante planches."

CH. LE Blanc, "MANUel DE L'Amateur D'estampes," Vol. II., pp. $539-540$.

\section{A Pastoral.}

Le Blanc, No. 40. 


\section{A Pastoral.}

Le Blanc, No. $4 \mathrm{I}$.

These two plates were executed in 1769 , in aquatint, from the artist's own designs.

\section{JULIEN, SIMON. [FRENCH SCHOOL, I735-1800.]}

Simon Julien was born at Toulon in 1735 . He studied under Dandré-Bardon at Marseilles, and under Carle Van Loo at Paris. In 1760 he gained the "Grand Prix de Rome." He remained in Rome for ten years, and in 1776 returned to Paris, where he died on February 23, r8oo.

Prosper de Baudicour describes eight etchings by this artist.

$$
\text { The Holy Family. }
$$

Baudicour, No. 4.

Etched in 1773 .

COULET, ANNE PHILIBERTE. [French School,

Born at Paris in 1736 .

I $736-(?)$.

A pupil of Jean Jacques Aliamet and Louis Simon Lempereur. In 1770 she was received into the Academy of France, and in $177 \mathrm{I}$ became a member of the Academy of Vienna.

She engraved several landscapes and sea-pieces, especially those of Joseph Vernet, which are charmingly etched and finished with the graver.

CH. LE BlanC, "MAnUel DE L'Amateur D'estampes," Vol. II., pp. $57-58$.

\section{Fishermen Throwing Their Nets.}

Le Blanc, No. 7 .

Engraved after the painting by Joseph Vernet.

Joseph Vernet was born at Avignon on August 14, I7I4. He went to Rome and the works he sent home excited so much ad- 
miration that Madame de Pompadour begged him to settle in Paris. On returning to France he was, in I753, admitted to the Academy, and in 1766 to its council. Soon after this Louis XV. commissioned him to paint a set of twenty pictures of French seaports.

Nine years were spent in the undertaking, but, owing to the war with England, sixteen pictures only were finished, the Channel ports being omitted.

These paintings are now in the Louvre. Vernet died on December 3, i 789 .

\section{PIROLI, TOMMASO. [ItAlian School, I750-I 824.]}

Born at Rome in $175^{\circ}$. Received his instruction in Florence. In 1806 he returned to Rome, in which city, after having passed some years in Paris, he finally settled, and died in 1824 . His prints are numerous, etched in outline, and in the chalk manner.

Besides the series of plates of the "Last Judgment," he etched the Prophets and Sibyls of Michael Angelo in the Sistine Chapel; the story of Cupid and Psyche, from the frescoes of Raphael in the Farnesina, and engraved the outlines for Flaxman's illustrations to Homer, Hesiod, Eschylus and Dante, under Flaxman's own directions, in Rome. There are also several other series of engravings by him, including plates of the remains of ancient art, bronzes, etc.

\section{The Last Judgment.}

A series of seventeen plates, after the fresco by Michael Angelo, in the Sistine Chapel.

This set is incomplete. Eleven of the seventeen only are here; plates $3,6,12,13,1_{5}$ and 17 are missing.

It is stated in "Bryan's Dictionary of Painters and Engravers" that Piroli engraved his series after the twelve plates of "The Last Judgment" by Conrad Martin Metz. Both sets were published in the same year, 1808 .

The Sistine Chapel was built by Baccio Pintelli, in 1473 , for Pope Sixtus IV. The upper portion of the walls is decorated in fresco by the great Florentine masters of the fifteenth centuryPerugino, Luca Signorelli, Sandro Botticelli and Cosimo Roselli. The ceiling is frescoed by Michael Angelo and is considered his 
finest work. Here his great spirit appears in its noblest dignity, in its highest purity; here the attention is not disturbed by that arbitrary display to which his great power not unfrequently seduced him in other works.

It was when Michael Angelo was already in his sixtieth year that Clement VII. formed the idea of effacing the three pictures of Perugino at the end of the Chapel, and employing him to paint, in their place, the vast fresco of "The Last Judgment." It occupied the artist for seven years, and was finished in I54I when Paul III. was on the throne. To induce him to pursue his work with application, Paul III. himself went to his house attended by ten cardinals ; "an honor," says Lanzi, "unique in the annals of art." The Pope wished that the picture should be painted in oil, but Michael Angelo refused to employ anything but fresco, saying that oil painting was work for women and for idle and lazy persons.

In the upper half of the picture we see the Judge of the world, surrounded by the apostles and patriarchs; beyond these, on one side, are the martyrs; on the other the saints, and a numerous host of the blessed. Still higher, under the two arches of the vault, two groups of angels bear the instruments of the Passion. Below the Saviour another group of angels, holding the books of life, sound the trumpets to awaken the dead. On the right is represented the resurrection; and higher, the ascension of the blessed. On the left, hell, and the fall of the condemned, who audaciously strive to press to heaven.

Retouched, faded, and discolored with smoke, it is now more valuable as a school of design than as a fine painting. Beautiful it is not-but it is more, it is sublime; sublime in conception, and astonishing in execution.

Paul IV., in an unfortunate fit of prudery, was seized with the resolution of whitewashing over the whole of the Last Judgment, in order to cover the scandal of a few naked female figures. With difficulty he was persuaded to spare it, but he caused Daniele da Volterra to add clothing to these figures.

"And, finally, there is the gigantic fresco at the far end, the Last Judgment with its swarming multitude, so numerous that days and days are needed to see each figure aright, a distracted crowd, full of the hot breath of life, from the dead rising in response to the furious trumpeting of the angels, from the fearsome groups of the damned whom the demons fling into hell, even to Jesus the Justiciar, surrounded by the saints and apostles, and to the radiant concourse of the blessed who ascend upheld by angels, 
whilst higher and still higher other angels, bearing the instruments of the Passion, triumph as in full glory. And yet, above this gigantic composition, painted thirty years subsequently, in the full ripeness of age, the ceiling retains its ethereality, its unquestionable superiority, for on it the artist bestowed all his virgin power, his whole youth, the first great flare of his genius." (Émile Zola, "Rome," Chap. VI., pp. I85-I86.)

The student will find descriptions of this wonderful Sistine Chapel in Hare's "Walks in Rome" (pp. 606-6r6), Eaton's "Rome," and Mrs. Jameson's "Sacred and Legendary Art."

\section{TARDIEU, PIERRE ALEXANDRE. [French School,

$$
\text { I 756-I 844.] }
$$

Born at Paris in 1756 . Pupil of his uncle, Jacque Nicolas Tardieu, and of Johann Georg Wille. His uncle, brother and nephew were all engravers of distinction, and among his pupils were Desnoyers, Bertonnier and Aubert.

With Bervic (whom he succeeded in 1822 as a member of the Institute), Tardieu marks the transition from the engravers of the eighteenth to those of the nineteenth century, and to the efforts of these two artists is due, in a large measure, the position that line engraving occupies in France to-day.

He engraved a number of plates, including many fine portraits, and died at $P$ aris in 1844 .

HENRI BERALDI, "LES GRAVEURS DU XIXe SIÈCLE," Vol. XII., pp. $7 \mathrm{I}-74$.

\section{Ruth and Boaz.}

Engraved from the picture by Louis Hersent (I777-I860) painted in 1822 .

Autograph presentation proof.

\section{MORGHEN, RAPHAEL. [ITALian School, I76I-I833.]}

Born at Portici, near Naples, June I4, I76r. At first a pupil of his father and uncle, he displayed such abilities as a draughtsman and engraver in a series of Masks from the Carnival held at 
Naples in 1778 , that he was sent to Rome for better instruction under Volpato, who, with Bartolozzi, had been a pupil of Wagner at Venice. Here Morghen made rapid progress, and in $178 \mathrm{I}$ engraved from Raphael's lunettes in the Vatican, the allegorical figures representing Poetry and Theology, to which he afterwards added those of Justice, Philosophy and Jurisprudence. He also worked for a time in conjunction with Volpato, whose daughter, Dominica, he married. He assisted Volpato in his "Parnassus," after Raphael, but soon surpassed his master. Many other important works followed, among them, "The Last Supper," after Leonardo da Vinci ; "The Transfiguration," and the "Madonna della Sedia," after Raphael, and the portrait of Francesco di Moncada, after Van Dyck.

In 1793 Morghen was appointed Professor of the Academy at Florence by the Grand Duke Ferdinand III. He was a member of several academies, and a corresponding member of the Institute of France. He was invited by Napoleon to take up his residence in Paris, but preferred to remain in his native country. He died at Florence, April 8, I833, and was buried in the Church of Santa Croce.

"But it was in Italy, toward the end of the last century, that engravers arose who, from our point of view, have given the world the most beautiful examples of great paintings reproduced by great engravers. Without losing sight of the precious work of old Dürer and his contemporaries, or of the unsurpassed technique of Edelinck, Drevet and Wille, yet it must be said that the best examples of beautiful pictures, beautifully engraved, are to be found among the works of the Italian engravers from Raphael Morghen to Toschi. They may not be such curiosities as the earlier prints, but to all who love a work of art for its beauty rather than for its rarity they are the best, being better adapted for framing and decorative purposes than any others.

Probably no engraver has so large a following of admirers as Raphael Morghen. This is partly due to his soft and captivating style, and partly to his excellent judgment in the choice of subjects. Morghen has preserved to the world the almost extinct glories of Leonardo da Vinci's 'Last Supper' in a plate which alone would have made the reputation of any engraver. Other fine examples of his work are the 'Aurora' of Guido, and the pair, after Poussin, of the 'Repose in Egypt' and the 'Dance of the Hours.'

A monument in the Church of Santa Croce-the Westminster Abbey of Florence-places Raphael Morghen among the 
mighty dead of Italy." (Frederick Keppel, "The Golden Age of Engraving," p. I2.)

WILLIS O. CHAPIN, "THE MASTERS AND MASTERPIECES OF ENGRAVING."

FREDERIC ROBERT HALSEY, "RAPHAEL MORGHEN'S ENGRAVED WORKS."

FREDERICK KEPPEL, "THE GOLDEN AGE OF ENGRAVING."

NICCOLÓ PALMERINI, “ OPERE D'INTAGLIO DEL CAV. RAFFAELLO MORGHEN."

CHARLES SUMNER, "THE BEST PORTRAITS IN ENGRAVING."

\section{Angelica and Medoro.}

Palmerini, No. 133 .

After the painting by $\mathrm{T}$. Matteini.

Second state; before the verses.

The scene is from Ariosto's "Orlando Furioso," Canto xix., stanza $3^{6}$, where the poet has made the idyllic loves of these two characters world-famous.

Impressions are rare, as Morghen, having been told that the subject was not such a one as should be treated by a good Catholic, suppressed all the proofs that could be repurchased.

"There is probably no finer example in engraving of the treatment of flesh and nude figures; and in these respects Morghen is seen at his best in the early impressions of this plate." (F. R. Halsey, "Raphael Morghen's Engraved Works," p. ז 2.)

\section{Portrait of General Francesco di Moncada.}

Palmerini, No. I62.

Halsey, No. I2 I.

Engraved after the painting by Van Dyck.

Fifth state; before the cross-hatchings on the armor.

Engraved at Rome, I792. The plate was finished toward the end of this year, having been begun only ten months before, and is sometimes called Morghen's Horse. It is, without doubt, the most famous engraved portrait of the master.

Francesco di Moncada was born at Valencia, Spain, in I586, and died in 1635 . He devoted himself to a military career from his 
youth. He commanded the Spanish flotilla at the siege of Dunkerque ; went to Vienna as ambassador for Philip IV., and in 1633 took command of all the Spanish forces in the Low Countries. The original Van Dyck portrait was in the Braschi Palace, Rome, when this plate was engraved, but it is now in the Louvre, Paris. See Villot, No. 146; Smith's Catalogue Raisonné, 143; Waagen, Handbook, II., 287. Both the painting and Morghen's engraving have been greatly admired. The latter is the engraver's most ambitious effort in portraits, and a wonderful specimen of the art. The effect is marred by the peculiar appearance of the horse when compared to modern equine types, but for this Van Dyck should be held accountable.

"Each hair on the horse seems to be reproduced from nature with a minuteness and realistic effect never before achieved, and which would be practically impossible in painting, the truthfulness of the engraving thus making amends, so to speak, for the absence of color." (F. R. Halsey, "Raphael Morghen's Engraved Works," p. xviii.)

\section{LAUGIER, JEAN NICOLAS. [FRENCH SCHOOL, I785-1865.]}

Born at Toulon in 1785 . He studied under Girodet, and at the École des Beaux-Arts, which he entered in $181_{3}$, and made rapid progress as an engraver. From $181_{5}$ to 1830 most of his plates were engraved after the works of David, Gérard, Girodet and Gros, when he turned his attention to the old masters. For a number of years he resided in Italy, but returned to France in r 840 , when he took up his residence at Argenteuil, where he died in 1865 .

HENRI BERALDI, "LES GRAVEURS DU XIXə. SIÈCLE," Vol. IX., pp. $5^{6-58 .}$

GUSTAVE LAMBERT, “J. N. LAUGIER, GRAVEUR D'HISTOIRE, SA VIE ET SES CEUVRES."

CHARLES LE BLANC, "MANUEL DE L'AMATEUR D'ESTAMPES," Vol. II., p. 502.

\section{Pygmation and Galatea.}

Beraldi, No. 25 .

Le Blanc, No. 5 .

Engraved in 1824 from the painting by Anne Louis Girodetde-Roussy-Trioson ( $1757-1824$ ).

The plate was destroyed after a few impressions had been printed from it, and proofs are, consequently, rare. 
LEISNIER, NICOLAS AUGUSTE. [FrenCH School, I787I862.]

Born at Paris in 1787 . A pupil of Halbon. In 1834 he was made a Knight of the Legion of Honor, and died in 1862 . He engraved several portraits, a number of plates for illustrations to books of travel, and some plates from the works of the old masters. His style is not characterized by any marked originality.

HENRI BERALDI, “LES GRAVEURS DU XIXe. SIÈCLE,” Vol. IX., pp. 107-108.

\section{La Fornarina.}

Beraldi, No. I3.

Engraved in 1834 from the painting by Raphael (or Sebastian del Piombo) in the Uffizi Palace, Florence. The painting is dated I 5 I 2 and is considered, by some authorities, to be a portrait of Vittoria Colonna; of the Improvisatrice Beatrice da Ferrara by others.

\section{DELACROIX, FERDINAND VICTOR EUGÈNE.} [FRENCh SCHOOL, I799-1863.]

Born at Charenton St. Maurice, near Paris, April 26, I799. He received his first instruction at the Lycée Impérial, and in I8I7 entered the studio of Guérin, where among his fellow-pupils were Géricault, Ary Scheffer, Henriquel-Dupont and Cogniet. His first work, "Dante and Virgil," exhibited in 1822 , achieved a great success. Through it he obtained admission to the studio of Baron Gros, and might have arrived at great academic honors but for his divergence from the prevalent classicism. This breach widened, and Delacroix and Géricault became the leaders of the Romantic school. The conflict between the rival schools was very bitter, and it was not until after the Revolution of 1830 that Delacroix and the Romanticists began to receive a share of the State patronage which, in France, exercises so strong an influence on art. In I83I he visited Spain, Morocco and Algiers, and in 1832 , through the influence of $M$. Thiers, he obtained his first public commission. Between this time and 1855 he executed a number of important public commissions, decorating the Galerie d'Apollon in the 
Louvre, the Salon de la Paix in the Hotel de Ville, the Library of the Luxembourg, and other buildings.

In 1831 he was made a Knight of the Legion of Honor, an Officer in 1846 , and Commander in 1855 . In 1857 he was elected a member of the Institute of France, and on August I3, I863, he died in Paris.

The lithographs of Delacroix, notwithstanding their peculiarities in drawing, show what vigor and color the lithographic crayon can acquire in the hand of a master. The "Hamlet" series has been much criticised, but M. Beraldi, in his work, "Les Graveurs du XIX'. Siècle," places it amongst the artist's finest work in lithography.

HENRI BERALDI, "LES GRAVEURS DU XIXe. SIÈCLE," Vol. V., pp. 154-166.

ATHERTON CURTIS, "SOME MASTERS OF LITHOGRAPHY," pp. 6772.

ADOLPHE MOREAU, "DELACROIX ET SON CEUVRE."

ALFRED ROBAUT, “L'EUVRE COMPLET DE EUGÈNE DELACROIX."

\section{The Blacksmith. (Aquatint.)}

Moreau, No. $21 . \quad$ Robaut, No. 459.

Second state.

One of the master's finest plates.

A Jewess of Algiers. (Etching.)

Moreau, No. 19 .

Robaut, No. 46 I.

First state.

\section{Illustrations to "Hamlet." (Lithographs.)}

Moreau, Nos. 76-91. Robaut, Nos. 577-597.

From a series of sixteen lithographs.

At the death of Delacroix the lithographic stones of this series were purchased by M. Paul Meurice, who had a few proofs printed from them and then had the stones framed. 
The Queen Tries to Cheer Hamlet.

Queen: "Good Hamlet, cast Thy nighted colour off, And let thine eye look like a friend on Denmark."

\section{Hamlet Wishes to Follow the Ghost of His Father.}

Hamlet: "Still am I call'd;-unhand me, gentlemen ;

By heaven, I'll make a ghost of him that lets me:-"

\section{Polonius and Hamlet.}

Polonius: "What do you read, my lord?"

Hamlet: "Words, words, words !"

\section{The Players Representing the Death of Hamlet's Father.}

Hamlet: "'Tis a knavish piece of work: But what of that ? Your majesty, and we that have free souls, it touches us not. . . . He poisons him i' th' garden for his estate. . . . The story is extant, and written in very choice Italian."

\section{Hamlet and Guildenstem.}

Hamlet: "Will you play upon this pipe?"

Guildenstern: "My lord, I cannot."

Hamlet: "I pray you."

\section{Hamlet Tempted to Kill the King.}

Hamlet: "Now might I do it, pat, now he is praying;

And now I'll do 't ; - and so he goes to heaven :

And so am I reveng'd? That would be scann'd."

\section{Hamlet and the Queen.}

Queen: "O, speak to me no more ;

These words, like daggers, enter in mine ears ;

No more, sweet Hamlet." 


\section{The Death of Polonius.}

Hamlet: "Indeed, this counsellor

Is now most still, most secret, and most grave,

Who was in life a foolish prating knave."

\section{The Death of Ophelia.}

Queen: "Her clothes spread wide;

And, mermaid-like, a while they bore her up."

\section{The Death of Hamlet.}

Hamlet: "Horatio, I am dead ;

Thou liv'st ; report me and my cause aright

To the unsatisfied."

CORR, ERIN. [Belgian School, I803-I862.]

Born of Irish parentage at Brussels in 1803 . After studying under De Meulemeester, he went to Paris and completed his training under Wedgwood and Forster. On returning to the Nethererlands he soon acquired a reputation by his engravings, and became, in 1832 , Professor of Engraving at the Antwerp Academy. He died in Paris on the roth of August, 1862.

\section{The Elevation of the Cross.}

After the painting by Peter Paul Rubens in Antwerp Cathedral. The original picture is in three parts (this being the central portion), and is fourteen feet high and fifteen feet wide. The left wing, in the original, represents the Virgin, with St. John and the holy women; the right wing shows mounted Roman soldiers superintending the crucifixion of the two thieves. The groups on the wings are painted on the inside of the covers of the middle part.

It was painted in 1610 for S. Walburge, Antwerp, and in 1627 was retouched by Rubens, who then introduced the Newfoundland dog in the right-hand corner. In 1796 the picture was carried to Paris, but it was returned to Antwerp in 1815 . 
This proof shows the condition of the plate as it was at the death of Corr. It is specially interesting as being etched throughout as a preliminary to the burin work, and is a good example of the method used by nearly all engravers of large plates-firstly to etch the subject, and afterwards to work upon the plate with the burin.

\section{NANTEUIL, CÉLESTIN. [FRENCH School, I813-1873.]}

Born at Rome, of French parents, in $18 \mathrm{r}_{3}$. He was brought to France when only two years old, and studied art under J. M. Langlois and Ingres. In 1829 he entered the École des BeauxArts, but was expelled for heading a students' disturbance. $\mathrm{He}$ was a prominent figure in the Romantic movement, a friend of Gautier, Victor Hugo, Dumas and others, and an illustrator of astonishing fertility.

In 1845 he turned his attention seriously to lithography, and produced works which rank, together with those of Mouilleron, Français and Laurens, as the finest reproductive lithographs of the century. He was president of a committee entrusted with the task of reorganizing the Fine Arts in 1848 , and at the fall of the Empire accepted the post of Director of Fine Arts at the Dijon Academy.

He obtained medals in 1837 and 1848 , and in 1868 was made a Knight of the Legion of Honor.

He died at Marlotte in 1873 .

His lithographs number several hundreds, and are, together with his etchings, of a very high order of merit. His lithographs after his own paintings are not the least interesting portion of his extensive work.

HENRI BERALDI, "LES GRAVEURS DU XIXe. SIÈCLE," Vol. X., pp. I64-I 88 .

PH. BURTY, “L'AGE DU ROMANTISME : CÉLESTIN NANTEUIL, GRAV. EUR ET PEINTRE."

\section{The Alchemist.}

After the painting by Eugène Isabey. 


\section{A Cottage Interior.}

After the painting by Adriaan van Ostade.

$$
\text { In the Woods. }
$$

After the painting by Eugène Isabey.

\section{Mother and Child in the Balcony.}

After the painting by Célestin Nanteuil.

LEROY, ALPHONSE. [French School, Contemporary.]

Has engraved a number of vignettes after Philippoteaux for a History of France. Works in line and stipple engraving. lished.

Resides in Paris, where his work has been executed and pub-

CH. LE BlanC, "MANUel De L'AMATEUR D'estampes," Vol. II., p. $54 \mathrm{I}$.

Study for the Figure of a Man Blowing a Trumpet.

After the drawing by Peter Paul Rubens.

The original drawing was made upon tinted paper, in crayon, strengthened in the high lights with white, and was in the collection of M. Frédéric Villot.

It was probably made as a figure-study for a "Triumph of Bacchus"; but Rubens does not seem to have used it in any picture.

\section{A Group of the Apostles.}

After the drawing by Titian.

The original drawing is in the Louvre.

This study was Titian's first conception for the lower part of 
his great picture, "The Assumption of the Virgin," painted in I5I6-15I 8 for the high altar of S. M. dei Frari in Venice, and now in the Academy of Fine Arts in Venice.

The painting was first exposed to public view on March 20, I5 18 . By the latter part of the sixteenth century it had become so dimmed by candle smoke as scarcely to be seen, and the French, at the time of their occupation of Italy, did not think it worth carrying away.

The upper portion is well preserved. The lower part has been injured by cleaning and extensive repainting.

The original drawing once formed part of the Mariette Collection.

\section{Judith with the Head of Holofernes.}

From the drawing by Andrea Mantegna.

(For note on Mantegna, see catalogue of the George C. Cooper Bequest.)

Judith was a native of Bethulia. In order to deliver her native city, which was besieged by Holofernes, a general of the King of the Assyrians, she entered the Assyrian camp under pretense of wishing to betray her city, gained admission to the general's tent by means of her extraordinary beauty, and slew him in his drunken sleep. The story dates from about $\mathbf{I}_{3} \circ \mathrm{B}$. C.

\section{CHIFFLART, NICOLAS FRANÇOIS. [FrENCH School, CONTEMPORARY']}

Born at Saint Omer in 1825. Painter, etcher and illustrator. In 185 I he took the "Grand Prix de Rome." He has etched, besides several series of plates, twelve illustrations for the Song of Roland (the plates being finished by Foulquier), and also drawn upon wood illustrations for "The Toilers of the Sea" of Victor Hugo.

P. G. HAMERTON, "ETCHING AND ETCHERS," pp. 208-2II.

"His plates are, at the same time, very original in conception, and very pure examples of a particular kind of technical work in etching. He is far from being faultless, and is not at all what a severe and prudent critic would recommend as a 'safe man,' but 
with all his errors he has really something to express, and expresses it with the utmost directness. . . . Chifflart is far too completely the artist to tolerate the slightest approach to false finish of any kind; therefore, when he improvises, he shades just as he draws, hewing out the forms by means of shadow, but no more. The drawing is everywhere inaccurate, yet not more inaccurate than the drawing in the hasty sketches of the great masters. That of Rembrandt is often equally imperfect, that of Michael Angelo occasionally." (P. G. Hamerton, "Etching and Etchers," pp. 208-2 I I.)

\section{Megara.}

\section{A Rocky Landscape.}

A Wood Interior. 






